\title{
Effects of Potentilla fulgens on Tuba Uterina in Ovariectomized Rats
}

\author{
Efectos de Potentilla fulgens en la Tuba Uterina de Ratas Ovariectomizadas
}

\author{
Zuat Acar*; U. Deger*; Ü. Görkem**; Cihan Togrul"** E. Deveci**; ${ }^{* *}$ S. Kaya**** \& A. Ekinci*****
}

ACAR, Z.; DEGER, U.; GÖRKEM, Ü; TOGRUL, C.; DEVECI, E.; KAYA, S. \& EKINCI, A. Effects of Potentilla fulgens on tuba uterina in ovariectomized rats. Int. J. Morphol., 34(2):460-464, 2016.

SUMMARY: A total of 32 Wistar rats were divided into four equal groups: (I) sham, (II) ischemia, (III) reperfusion and (IV) Potentilla fulgens. In groups I and II, ovary torsion was not performed and no drug was administered. In group III, $1 \mathrm{~h}$ of ischemia and $2 \mathrm{~h}$ of reperfusion were performed and no drug was given. Group IV received $400 \mathrm{mg} / \mathrm{kg} /$ day Potentilla fulgens intraperitoneally 5 days before Ischemia-reperfusion. All the parameters were observed to be significantly decreased $(\mathrm{P}<0.05)$ in all the experimental groups compared to the control group. In the sections of the ischemia-reperfusion group, degeneration of epithelium, dilation of blood vessels were observed. Potentilla fulgens administration reduced the morphological changes by induced I/R; in particular, infiltration, hemorrhage and vascular dilatation were decreased. Potentilla fulgens application during torsion, it plays an important role in maintaining the epithelial structure with E-cadherin expression. We suggest that PECAM-1(CD31) are a regulator of the microvascular response of the tubal mucosa.

KEY WORDS: Potentilla fulgens; Ischemia-reperfusion; Tuba uterina; Rat.

\section{INTRODUCTION}

Potentilla fulgens is an alpine plant of Western Himalayas which is consumed in all parts of the world for its promising medicinal properties. Pharmacologically, the aerial and root portions of the plant are reported to have antioxidant (in vitro models), antitumor, hypoglycemic and antihyperglycemic activities (Kaul et al., 2011; Syiem et al., 2003 , 2009). The general signs and symptoms of toxicity, food and water intake and mortality rates of animals were observed within $72 \mathrm{~h}$ post-treatment. From these observations, LD50 was calculated using SPSS software (Chen et al., 2005). The roots of the plant are used traditionally to treat ailments including gastric problems (peptic ulcers), mouth ulcers, diarrhea, gingivitis, diabetes, anthelmintic, cures pyorrhea and even improves gums (Kaul et al., 2011). CD31 antigen (PECAM-1) is a single chain transmembrane glycoprotein with a molecular weight of 130 to $140 \mathrm{kD}$. The CD31 molecule is expressed on the surface of platelets, monocytes, granulocytes. The properties of CD31 antigen suggest that it is involved in interactive events during angiogenesis, thrombosis and wound healing (Leica Biosystems, 2016). E-cadherin is a calciumdependent transmembrane protein involved in homotypic cell- cell interactions (Angst et al., 2001). This adhesive molecule allows neighboring cells to stick together, it is also involved in the regulation of signaling events (Ozawa \& Kemler, 1992; Aberle et al., 1996). E-cadherin, epithelial cell differentiation and proliferation have been shown to act at the cell-cell connectivity.

In this study, we aimed to investigate the protective effects of Potentilla fulgens against the tuba uterina ischemia reperfusion (I/R) injury in rats by means of biochemical, histopathological, and immunohistochemical examination.

\section{MATERIAL AND METHOD}

The permission for the animal tests and experiments was given by the Animal Ethical Board of Dicle University Medical Faculty. Dicle University's Experimental Animal Laboratory Institute supplied 30 healthy adult female wistar rats, weighing between 180 and $210 \mathrm{~g}$. The rats were selected

\footnotetext{
* Department of Obstetrics and Gynecology, Memory Hospital, Diyarbakır, Turkey.

** Hitit University Faculty of Medicine, Department of Obstetrics and Gynecology, Çorum, Turkey.

*** Dicle University Faculty of Medicine, Department of Histology and Embryology, Diyarbakır, Turkey.

****Department of Biochemistry, Faculty of Medicine,University of Dicle, Diyarbakır, Turkey.
} 
according to their estrous cycle The rats were housed in plastic rat cages at $26 \pm 2{ }^{\circ} \mathrm{C}$ and they were exposed to $10-12$ $\mathrm{h}$ of day light. Animals were fed a standard laboratory diet and tap water ad libitum. A total of 32 Wistar rats were divided into four groups The rats were first numbered randomly and then randomly divided into 4 equal groups: Sham, torsion, detorsion and Potentilla fulgens groups. In group I $(n=8)$ sham, in group II ovary torsion was not performed and no drug was administered. In group III $h$ of ischemia and $2 \mathrm{~h}$ of reperfusion were performed and no drug was given. In group IV, The Potentilla fulgens group received $400 \mathrm{mg} / \mathrm{kg}$ per day Potentilla fulgens intraperitoneally 5 day before Ischemia-reperfusion injury. Each rat was administered intramuscular ketamine hydrochloride $(50 \mathrm{mg} /$ $\mathrm{kg}$ ketamine hydroxide) and xylazine hydrochloride $(10 \mathrm{mg} /$ $\mathrm{kg}$ Rompun, Bayer Istanbul, Turkey) for anesthesia. The rats, except for in the sham-operated group, were subjected to right unilateral adnexial torsion which induced ischemia by occlusion of the tuba-ovarian vessels for $2 \mathrm{~h}$. Rats in sham group were subjected to laparatomy only. In the torsion group, ovaries were surgically removed after $2 \mathrm{~h}$ of torsion. Right ovaries were surgically removed in all groups. The tuba uterina tissues were fixed in $10 \%$ neutral buffered formalin solution for $24 \mathrm{~h}$, dehydrated, cleared, and embedded in paraffin as usual. Serial tissue sections at a thickness of 4-5 $\mathrm{mm}$ were cut using the microtome and stained with hematoxylin and eosin (H\&E).

Immunohistochemistry. Formaldehyde-fixed tissue was embedded in paraffin wax for further immunohistochemical examination. Sections were deparaffinized in absolute alcohol. Endogenous peroxidase activity was blocked with absolute methanol containing $0.4 \%$ hydrochloric acid (1 $\mathrm{M})$ and $0.5 \%$ hydrogen peroxide (100 volumes) for $40 \mathrm{~min}$ at room. After washing in water followed by $0.05 \mathrm{M}$ Trisbuffered saline, the sections were incubated in $1 \%$ trypsin.

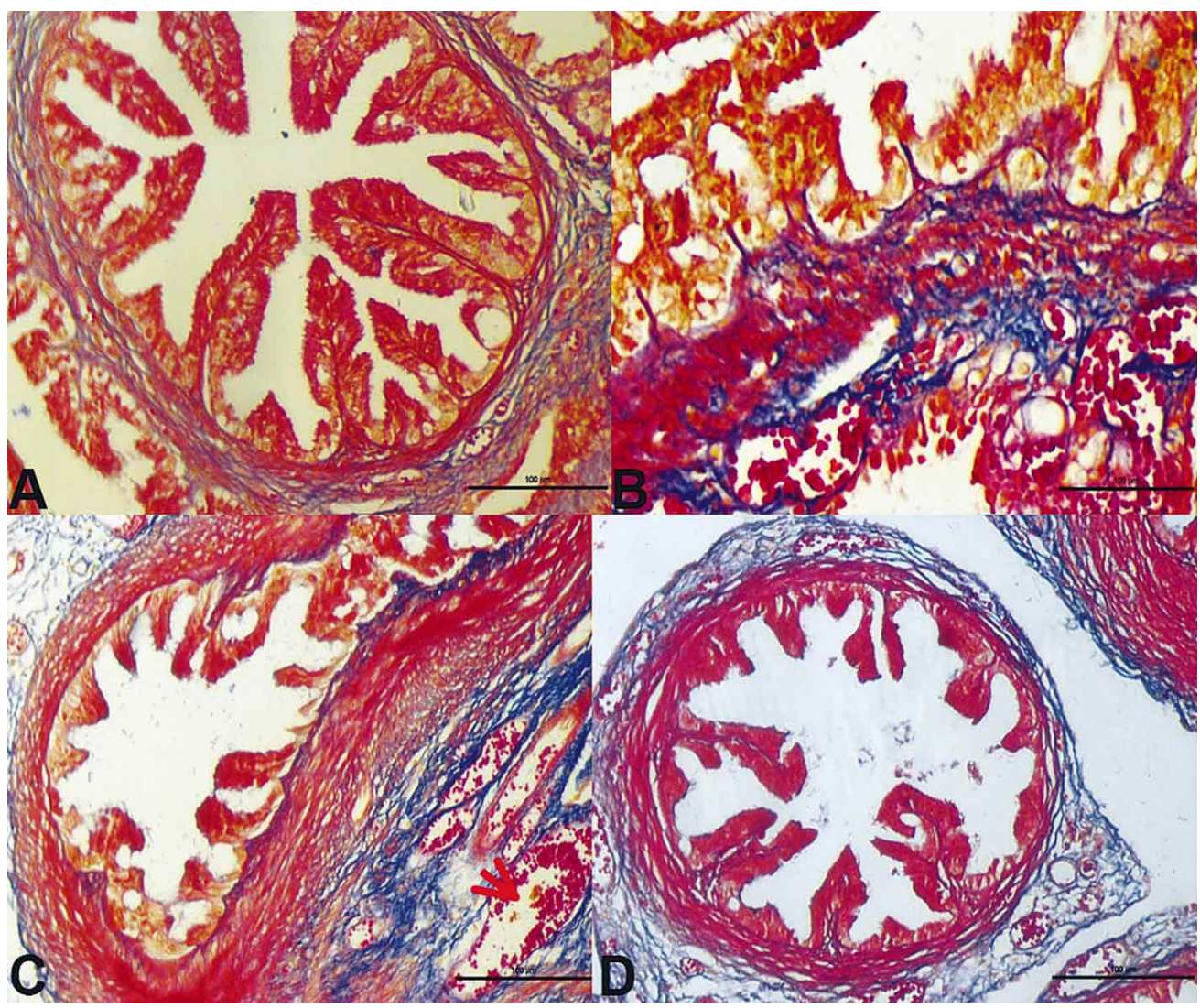

Fig. 1. A) The appreance showed in transvers section of tuba uterina (Control group) Mallory Azan stain Bar $100 \mu \mathrm{m}, \mathrm{B}$ ) Degeneration in surface epithelium, thinning of connective tissue fibers extending to the surface epithelium, dilatation and hemorrhage in blood vessels (arrow) (Ischemia group) Mallory Azan stain Bar $50 \mu \mathrm{m}$. C) Loss in mucosal extension, seperation in basal membrane, dilatation and hemorrhagie in blood vessel (arrow) (Ischemia-reperfusion group) Mallory Azan stain Bar $100 \mu \mathrm{m}$. D) In the Ischemia-reperfusion+Potentilla fulgens partially preserved in mucosal extentions and basal membrane Mallory Azan stain Bar $100 \mu \mathrm{m}$. 
After washing in cold water, staining was carried out as above, using E-cadherin (1/100), slides were incubated with ultra V-block and subsequently either with PECAM-1 (CD31) primary antibody used at a dilution of $1 / 100$. A biotinylated secondary antibody was applied for one hour. Slides were then exposed to streptovidin peroxidase and chromogen. After each treatment, the slides were washed in PBS. The slides, having been counter stained with Mayer's haematoxylin.

Statistical analysis. Statistical analysis was performed using commercially available soft ware (SPSS v.10.0, SPSS Inc., Chicago, IL, USA).The difference between the groups for nonparametric data with the Kruskal-Wallis test, two group comparisons Bonferonn correction was made after using the Mann-Whitney U test.

\section{RESULTS}

All the parameters were observed to be significantly decreased $(\mathrm{P}<0.001)$ in all the experimental groups compared to the control group.

The tubas uterinas of the 1schemia groups showed some cellular hypertrophy and hyperplasia of the columnar epithelium, In the ischemia group, vascular dilatation and congestions were observed in tunica mucosa and sub epithelial area, the epithelial surface and extending to the reduction in cilia structures was decreased. In the sections of the ischemia-reperfusion group, degeneration of epithelium, dilation of blood vessels were observed. Potentilla fulgens administration reduced the morphological

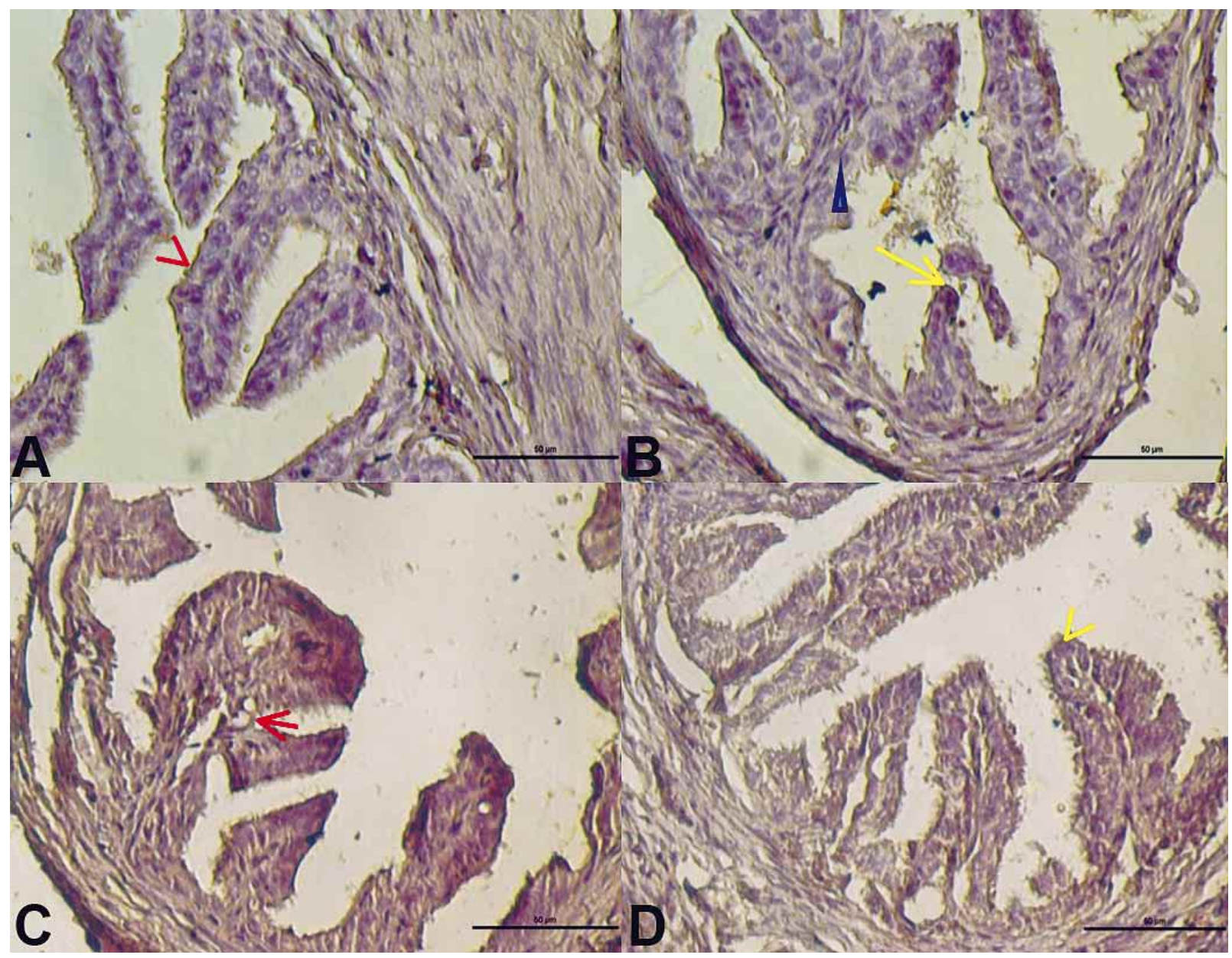

Fig. 2. A) Control group; E-cadherin positive expression in the cell apical cilia connections (arrow), E-cadherin immunstaining Bar $50 \mu \mathrm{m}$. B) In the ischemia group, Decomposition and degradation of the surface epithelial cell-cell connections(arrow), weak expression of E-cadherin in apoptotic cells, E-cadherin immunstaining Bar $50 \mu \mathrm{m}$. C) In the ischemia-reperfusion group, Degeneration and picnosis in the surface epithelium, breaking the cell-cell connections, E-cadherin immunstaining Bar $50 \mu \mathrm{m}$. D) In the ischemia-reperfusion + Potentilla fulgens group Cilia and the cell-cell connections regularly (positive E-cadherin expression), light leaving the basal part of the mucosal folds, E-cadherin immunstaining Bar $50 \mu \mathrm{m}$. 


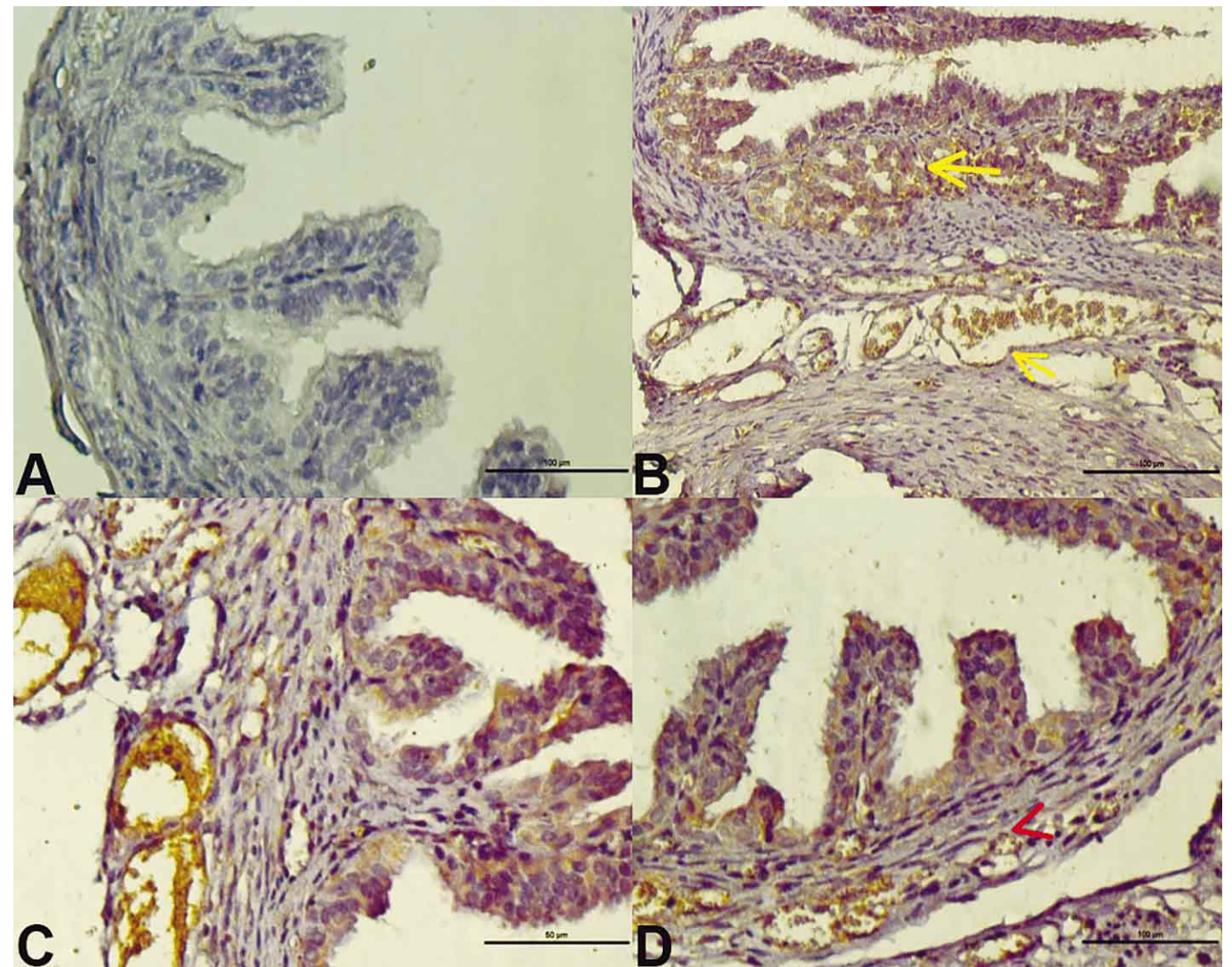

Fig. 3. A) In the section control group, Negative CD31 expression in transvers section of tuba uterina CD31 1mmunstaining Bar $100 \mu \mathrm{m}$. B) In the ischemia group, Positive CD31 expression in inflammatory cells and endothelial cells of blood vessels (arrow) CD31 immunstaining Bar $50 \mu \mathrm{m}$. C) In the ischemia-reperfusion group, CD31 expression in endothelial cells (arrow) CD31 immunstaining Bar $50 \mu \mathrm{m}$. D) In the 1schemiareperfusion+Potantilla fulgens group, positive CD31 expression in endothelial cells in small vessels (arrow) CD31 immunstaining Bar $100 \mu \mathrm{m}$,

changes by induced I/R; in particular, infiltration, hemorrhagie and vascular dilatation were decreased.

In the ischemia group ,the positive reaction inflamatory cells in sub epithelial and the blood vessels in the stromal region of CD31 expression was observed. As a result of ischemia, in which blood vessels dilate to fulgens treated group was observed near normal appearance.

\section{DISCUSSION}

Torsion of the ovary or tuba uterina (adnexal torsion) is an uncommon event. Rotation of the infundibulopelvic ligament causes compression of the ovarian vessels and impedes lymphatic and venous outflow and arterial inflow. Ovarian torsion occurs due to the rotation of the adnexa. The degree of rotation and duration of torsion determine the severity of the injury (Inderdeo et al., 1996).
MDA (Malondialdehyde) is a secondary product of oxidative stress formed during lipid peroxidation and is significantly increased by $\mathrm{I} / \mathrm{R}$ injury. It is released as a result of toxic effects of active oxygen species which destroy unsaturated fatty acids in the cell membrane (Melchiorri et al., 1995). In the present study, the levels of ovarian MDA were significantly decrease by I/R injury. Tunç et al. (2014) as the result of ovarian torsion, in the tuba uterina epithelial cilia loss, piknosis nucleus, while the submucosa showed that inflammation. Torsion due to lack of blood flow to the inability of the ovaries. In the epithelium of the tuba uterina it has caused the reduction of degeneration and delete it. We observed a typical cells with nuclei, congestion in blood vessels and inflammatory cell infiltration in the sections of tuba uterina in torsion group. In the present study, Potentilla fulgens prevented the hemorrhage and degree of vascular dilatation, and congestion. These effects of Potentilla fulgens may occur through its antioxidant properties. 
E-cadherin is an important molecule in the maintenance of epithelial integrity (Takeichi, 1990) Damage to the epithelium may result in loss of E-cadherin membrane expression and intercellular contacts (Nawijn et al., 2011).

In the torsion group, the expression of E-cadherin in epithelial degenerations was localized weakly in the intercellular border. In torsion + Potentilla fulgens group, E-Cadherin was expressed tuba uterina the whole surface of polarized epithelial cells. We observed an association between the expression of E-cadherin in tubal surface epithelium and the morphology of cells, with expression of
E-cadherin predominant in ciliar columnar cells. Potentilla fulgens application during torsion, it plays an important role in maintaining the epithelial structure with E-cadherin expression. In the torsion group, PECAM-1 expression showed positively vascular endothelial cells in submucosa, in addition PECAM-1 showed a significant increase in inflammatory cells

It is an important marker on a endothelial mitogen PECAM-1 (CD31) angiogenesis regulation. We suggest that PECAM-1 (CD31) are a regulator of the microvascular response of the tubal mucosa.

ACAR, Z.; DEGER, U.; GÖRKEM, Ü; TOGRUL, C.; DEVECI, E.; KAYA, S. \& EKINCI, A. Efectos de Potentilla Fulgens en la tuba uterina de ratas ovariectomizadas. Int. J. Morphol., 34(2):460-464, 2016.

RESUMEN: Un total de 32 ratas Wistar fueron divididas en cuatro grupos: (I) Sham, (II) isquemia, (III) reperfusión y (IV) Potentilla fulgens. En los grupos I y II, no se realizó la torsión de ovario y ni se administró ningún tipo de fármaco. En el grupo III, se produjo isquemia por $1 \mathrm{~h}$ seguido de reperfusión por $2 \mathrm{~h}$ (I/R), sin administracion de fármacos. El grupo IV recibió $400 \mathrm{mg} / \mathrm{kg}$ por día de Potentilla fulgens vía intraperitoneal durante cinco días previo al protocolo de isquemia-reperfusión. Se observó que todos los parámetros disminuyeron significativamente $(\mathrm{P}<0,05)$ en todos los grupos experimentales en comparación con el grupo control. En las secciones del grupo de isquemia-reperfusión, se observó degeneración del epitelio y dilatación de los vasos sanguíneos. La administración de Potentilla fulgens reduce los cambios morfológicos inducidos por I/R; en particular, la infiltración, la hemorragia y la dilatación vascular. La aplicación de Potentilla fulgens durante la torsión, desempeña un papel importante en el mantenimiento de la estructura epitelial con la expresión de E-cadherina. Sugerimos que PECAM-1 (CD31) es un regulador de la respuesta microvascular de la mucosa tubárica.

PALABRAS CLAVE: Potentilla fulgens; Isquemia-Reperfusion; Tuba uterina; Rata.

\section{REFERENCES}

Aberle, H.; Schwartz, H. \& Kemler, R. Cadherin-catenin complex: protein interactions and their implications for cadherin function. J. Cell. Biochem., 61(4):514-23, 1996.

Angst, B. D.; Marcozzi, C. \& Magee, A. I. The cadherin superfamily: diversity in form and function. J. Cell. Sci., 114(Pt. 4):629-41, 2001.

Chen, W.; Fu, X. B.; Ge, S. L.; Sun, T. Z.; Li, W. J. \& Sheng, Z. Y. Acid fibroblast growth factor reduces rat intestinal mucosal damage caused by ischemia-reperfusion insult. World J. Gastroenterol., 11(41):6477$82,2005$.

Inderdeo, D. S.; Edwards, D. R.; Han, V. K. \& Khokha, R. Temporal and spatial expression of tissue inhibitors of metalloproteinases during the natural ovulatory cycle of the mouse. Biol. Reprod., 55(3):498-508, 1996.

Kaul, K.; Jaitak, V. \& Kaul, V. K. Review on pharmaceutical properties and conservation measures of Potentilla fulgens Wall. ex Hook. - A medicinal endangered herb of higher Himalaya. Indian J. Nat. Prod. Resour., 2(3):298-306, 2011.

Leica Biosystems. The Pathology ComponyPECAM1 (CD31) Antibody. Wetzlar, Leica Biosystems, 2016. Disponible en: http:// www.leicabiosystems.com/ihc-ish/novocastra reagents/primary

Melchiorri, D.; Reiter, R. J.; Attia, A. M.; Hara, M.; Burgos, A. \& Nistico, G. Potent protective effect of melatonin on in vivo paraquat-induced oxidative damage in rats. Life Sci., 56(2):83-9, 1995.
Nawijn, M. C.; Hackett, T. L.; Postma, D. S.; van Oosterhout, A. J. \& Heijink, I. H. E-cadherin: gatekeeper of airway mucosa and allergic sensitization. Trends Immunol., 32(6):248-55, 2011.

Ozawa, M. \& Kemler, R. Molecular organization of the uvomorulin-catenin complex. J. Cell Biol., 116(4):989-96, 1992.

Syiem, D.; Syngkai, C.; Kharbuli, B.; Kayang, H. \& Khongwir, B. S. Antitumor activity of crude root extract of Potentilla fulgens. Indian Drugs, 40:124-5, 2003.

Syiem, D.; Khup, P. Z. \& Syiem, A. B. Effects of Potentilla fulgens Linn. On carbohydrate and lipid profiles in diabetic mice. Pharmacologyonline, 2:787-95, 2009.

Takeichi, M. Cadherins: a molecular family important in selective cell-cell adhesion. Аnпи. Rev. Biochem., 59:237-52, 1990.

Tunç, S. Y.; Ag açayak, E.; Yaman, N. S.; Deveci, E.; Kalkanlı, S. \& Özler, A. Effects of adnexal torsion on the Fallopian tube in rats: a histologic and immunohistochemical study. Anal. Quant. Cytopathol. Histpathol., 36(5):285-9, 2014.

Correspondence to:

Engin Deveci

Dicle University

Medical Faculty Histology and Embryology

Dept. 21280

Diyarbakir

TURKEY

Received: 08-10-2015

Accepted: $30-03-2016$

Email: engindeveci64@gmail.com 